\title{
Parenting Stress and Need Assessment of Families with Disabled Children across Himachal Himalaya
}

\author{
Randhir S. Ranta \\ Sr. Research Officer \\ Institute of Integrated Himalayan Studies, UGC Centre of Excellence \\ Himachal Pradesh University, Summer Hill, Shimla-171005 \\ Vijay Kumar Sharma \\ Project Officer, \\ Institute of Integrated Himalayan Studies, UGC Centre of Excellence \\ Himachal Pradesh University, Summer Hill, Shimla-171005 \\ Pankaj Gupta (Corresponding author) \\ Sr. Research Officer \\ Institute of Integrated Himalayan Studies, UGC Centre of Excellence \\ Himachal Pradesh University, Summer Hill, Shimla-171005 \\ E-mail: pkpmahajan@yahoo.co.in
}

Received: March 30, 2015 Accepted: June 12, 2015 Published: August 5, 2015

doi:10.5296/ijssr.v3i2.7344 URL: http://dx.doi.org/10.5296/ijssr.v3i2.7344

\begin{abstract}
The study pertains to the parenting stress, which is believed to be the resultant of child disability and further assesses the needs of the families across selected pockets of Himachal Himalaya. Perceived Stress Questionnaire (PSQ) and Need Assessment Scale were used for the purpose. For assessing the stress level among the parents, PQS was administered among two hundred parents having disabled children, herein called experimental group and two hundred parents with normal children, herein called control group. A three point Need
\end{abstract}


assessment scale was used to measure the needs of 200 families on five different parameters. The result of t-test shows the significant difference between experimental and control groups indicating that the parents of disabled children experience more stress than their control counterpart. The study indicates that people need proper guidance and information regarding a child's disability, nutritional requirements of a child, vocational training and child management. There is a need for proper counselling for parents suffering from stress and creating consciousness among parents of children with disabilities and in the society.

Keywords: Parenting stress, Perceived Stress Questionnaire, Need Assessment Scale, Child disability

\section{Introduction}

Nurturing a child with disabilities is a tough task for parents, which imposes additional financial burden on them, resulting in stress (Tew \& Laurence, 1975; Stein, 1988; Miller et al., 1992). Stress is a physical, mental or emotional reaction resulting from an individual's response to environmental tensions, conflicts, pressures, and similar stimuli (Agrawal, et al. 1979). Selye (1978) was perhaps the first one to use the term stress in psycho-physiological context. Lazarus and Folkman (1984) described psychological stress as a relationship between the person and the environment that is appraised by the person as taxing or exceeding his or her resources and endangering his or her well-being.

Researchers across the world have tried to give a suitable conceptualization for a specific type of stress, i.e. the parenting stress. One of the more commonly used indices of parenting stress is the Parenting Stress Index (PSI), which offers a valuable conceptualization for parenting stress. Abidin (1995), admits that stressors are multi-dimensional both in source and kind. He noted three source areas of stressors for parents: a) Child characteristics, b) Parent characteristics, and c) Situational/ demographic. Lavee et al. (1996) discussed various types of parenting and family stress that are the outcome of several stressful life events. There are several aspects, however, of both the child and the parent that could impairs this view of stress in the parenting role, and is probably the contributing factor to greater levels of perceived parenting stress. Lack of resources, including nutrition, treatment and resilient medical equipment adds to the stress of parents having disabled children. In situations of paucity, a child with a disability is considered as a liability, an evil spirit, and as an unfortunate child (Pal \& Choudhury, 1998). Baker et al. (2003) showed that parents of children with developmental delays experience greater stress than parents of normal children. Though an array of causes adds to the increased level of stress for caregivers of children with debilities, acuteness of child's behavior problems is often the toughest interpreter of parental stress (Floyd \& Gallagher, 1997; Hassall et al., 2005; Nachshen et al., 2005).

Needs has been described as the necessity stated by an individual for existence. Requirements identified by families and parents of disabled children vary from one family to another. Rao (2008) concluded that parents of mentally challenged children need sympathetic and considerate attitude from society. Some of them need financial help, while others require information pertaining to the nature of the disability, nutritional requirement of disabled children, etc. Singh et al. (2008) established a negative impact, which comprised of 
requirements for meeting the additional demands for physical care of the child, career adjustments, loss of support from family and society, etc. Verma and Kishore (2009) carried out the need assessment of Indian parents having children with intellectual disability and concluded that disability in children gives rise to various needs in parents, which may vary according to the nature of the disability and parental characteristics. The needs expressed by fathers and mothers differed significantly.

Evaluating parenting stress is a somewhat intricate process, in that there are possibly several components to be considered based on interactions of children, parents and environmental variables. Parenting stress is related with negative aspects of parental and family functioning in families of children with disabilities, which underlines the significance of exploring this type of stress. The purpose of the present study was to assess the parenting stress and need assessment of parents having disabled children. The present study hypothesized that there is no variance in the perceived stress level of parents of disabled children and parents of normal children.

\section{Methodology}

A qualitative surveying cross-sectional study method was used. The study was carried out in selected pockets of Himachal Pradesh. Himachal, unique landscape nestled in the northern part of the western Himalay is one of the Himalayan states, which is bordered by Tibet and China on the East, states of Uttrakhand on Southeast, Punjab on west and south-west, Jammu and Kashmir on North and Haryana and Uttar Pradesh on South. The pockets were selected from four agro-climatic zones of Himachal Pradesh, i.e. Sub-montane and low hills sub-tropical zone: (Zone-I); Mid-hills sub-humid zone: (Zone-II); High hills wet temperate zone: (Zone-III); High hills dry temperate zone: (Zone-IV). All pockets had varied socio-demographic physiognomies and are geographically apart. Being secluded from the rest of the region, because of mountainous terrain and inaccessibility of infrastructure, the caregiving for children in that area is especially troublesome for parents, especially, when the children are disabled. In some backward areas, transportation is often problematic and the situation becomes more challenging in snowbound areas. The study population is defined as: 'Children with disability and their families, living in selected pockets of Himachal Pradesh'. Purposive sampling technique was used for the study. From the database of Child Development Project Officer (CDPO), of each selected pocket, 20 cases were selected and interviewed. Parents or the caregivers of 200 children with disabilities were invited to take part in the study. All respondents had children who were identified with some disability. Similarly, 200 respondents of a control group were the parents of normal children who were selected from the same pockets. Apart from completion of the Perceived Stress Questionnaire (PSQ), an effort was made to assess the needs of family having disabled children using the Need Assessment Scale for Families of Persons with Disability (NASF- PWD).

\subsection{Participants}

Level of perceived stress was assessed in the parents having disabled children, i.e. the experimental group, \& the same was compared with that of parents having normal children. This group acted as the Control Group. 
Demographic profile of all the respondents was gathered with respect to their age, category, whether belonging to general category or scheduled Caste or scheduled Tribe, educational qualification and occupation. "Scheduled Castes" means such castes, races or tribes or parts of or groups within such castes, races or tribes as are deemed under article 341 to be Scheduled Castes for the purposes of Indian Constitution. The term Scheduled Tribes first appeared in the Constitution of India. Article 366 (25) defined scheduled tribes as "such tribes or tribal communities or parts of or groups within such tribes or tribal communities as are deemed under Article 342 to be Scheduled Tribes for the purposes of this constitution". Other Backward Class (OBC) is a collective term used by the Government of India to classify castes, which are socially and educationally disadvantaged. In the Indian Constitution, OBCs are described as "socially and educationally backward classes", and the Government of India is enjoined to ensure their social and educational development. In the experimental group, out of 200 respondents, 87.5\% were females, i.e. the mothers of disabled children and $12.5 \%$ were males, i.e. fathers of disabled children. The control group consisted of $15 \%$ males and $85 \%$ females. Still, an attempt was made to engage both the parents in the discussion. Most of the respondents (58.5\%) fall under age group 31-40 years, followed by 41-50 years (21.5\%) and 20-30 years (14.5\%). Only 5.5\% of the respondents were above 50 years of age. In the control group, $57 \%$ of the respondents belonged to age group 31-40 years, followed by $19 \%$ in the age group 41-50 years and $18 \%$ in the age group 20-30 years. Six percent of the control group respondents were above 50 years of age.

While interviewing about the category of experimental respondents, it was found that $46 \%$ respondents belonged to general category, while $24.5 \%$ belonged to Scheduled Caste and $22.5 \%$ to Scheduled Tribe. Only $7 \%$ of the respondents fall in the category of Other Backward Classes (OBC). In control group, $47 \%$ of the respondents were from general category, followed by $24 \%$ from Scheduled Tribe category, $19 \%$ from Scheduled Caste and $10 \%$ from OBC.

In experimental group, $39.5 \%$ of the respondents were educated up to eighth class, followed by $22 \%$ who were educated up to tenth standard. There were $11.5 \%$ parents who passed senior secondary level, followed by $9.5 \%$ graduates, 3\% postgraduates and remaining $14.5 \%$ illiterates. In control group, $32.5 \%$ respondents were educated up to senior secondary level, while $29.5 \%$ were educated up to tenth standard. Only $9.5 \%$ of the respondents were graduates while $6.5 \%$ respondents were illiterate.

\subsubsection{Instruments}

Perceived Stress Questionnaire revised by Fliege, (2004) was used to assess the stress level of parents. Perceived Stress Questionnaire (PSQ) is a twenty-item questionnaire of four scales with five items each, which are:

Scale 1: (Worries) covers worries, anxious concern for the future, and feelings of desperation and frustration.

Scale 2: (Tension) explores tense disquietude, exhaustion, and the lack of relaxation.

Scale 3: (Joy) is concerned with positive feelings of challenge, joy, energy, and security. 


\section{Macrothink \\ International Journal of Social Science Research \\ ISSN 2327-5510 \\ 2015, Vol. 3, No. 2}

Because all items of this scale are positively worded, we opted for a positive name.

Scale 4: (Demands) covers perceived environmental demands, such as lack of time, pressure, and overload.

An overall index score is calculated from all items. For this purpose, the scale "joy", which is positively coded, was inversed. A high overall PSQ score means a high level of perceived stress.

4 = Usually

$3=$ Often

2 = Sometimes

$1=$ Almost Never

\section{Dimensions}

Worries

Tension

Joy*

Demands

* Reverse Scoring
Items

$1-5$

$6-10$

$10-15$

$15-20$

\section{Need Assessment Scale for Families of Persons with Disability (NASF- PWD)}

The Need Assessment Scale for Families of Persons with Disability, evolved by Ranta et al. (2014) was devised to observe the needs of family member, i.e. the parents of disabled child. The scale has following five areas with five questions in each area:

Area-I (Need to know the condition of child)

Area-II (Child Management)

Area-III (Services)

Area-IV (Personal-Social)

Area-V (Unspecified Needs)

The scale has been designed as a three point scale to measure the impact of disability on the family. Scoring of the items was done by entering 2 points when the impact was very much, entering 1 point when the impact was little and 0 when there was no impact at all. In this manner, this scale scored a maximum 10 points in each area and 50 points including all the areas.

\subsubsection{Procedure}

Perceived Stress Questionnaire (PSQ) was translated in simple Hindi, the common language of people in and around the survey area. Questionnaire and scale were explained to the respondents to clearly get the appropriate response. Data were gathered anonymously and no identifiers were kept. The quantifiable data was analyzed by SPSS version 11 .

PSQ is a self-administration questionnaire and can be administered to a group or to an individual. For this purpose, the subject is seated comfortably in a well lit room, free of external distractions. The questionnaire along with pencil was given to the subject and instructed to answer the way he/she really feels. The subject was given instruction to indicate 


\section{Macrothink}

his/ her response by circling the appropriate number. There was no time limit. However, in many cases, where the subject was illiterate or less educated, they were asked each question along with their preference. The responses of the respondents to Need Assessment Scale for Families of Persons with Disability (NASF-PWD) were also translated in Hindi. Members of research team having good interviewing skills administered the scale. One person at a time was asked question and the score was entered in the given box.

\section{Results}

\subsection{Perceived Stress Difference through T Test}

Since there was difference in stress level of parents having disable children (herein called Experimental Group) and parents of normal children (herein called Control Group), t-ratio was computed and considered desirable to apply t-test on the score of worries, tensions, joy and demand. The results of t-test shows (Table 1 \& 2) the significant difference between Experimental and Control groups on the scores of worries $(\mathrm{t}=40.2, \mathrm{p}<.01)$, tension $(\mathrm{t}=73.3$, $\mathrm{p}<.01)$, joy $(\mathrm{t}=58.0,<.01)$ and demands $(\mathrm{t}=74.9, \mathrm{p}<.01)$. Hypothesis stated that there is no difference in the perceived stress level of parents having disabled children and parents having normal children. In view of above findings, this hypothesis stand rejected. The higher mean score (worries $=12.8$, tension $=11.8$, joy $=13.3$ and demands $=14.2$ ) indicate that the parents of disabled children experience more stress than their control counterpart. These parents differ significantly from their comparable controls $(\mathrm{df}=398, \mathrm{t}=40.2, \mathrm{p}<.01)$. Graph 1 shows the mean difference between parents of disable children and parents of normal children.

Table 1. Mean difference between the scores of Experimental Group (Parents having child with disability) and Control Group (Parents having normal child)

\begin{tabular}{lllllll}
\hline Variable & $\begin{array}{l}\text { Sample size } \\
\text { Experimenta } \\
\text { l Group }\end{array}$ & df & $\begin{array}{l}\text { Sample size } \\
\text { Control } \\
\text { Group }\end{array}$ & df & $\begin{array}{l}\text { Experimental } \\
\text { Group Mean }\end{array}$ & $\begin{array}{l}\text { Control } \\
\text { Group } \\
\text { Mean }\end{array}$ \\
\hline Worries & 200 & 199 & 200 & 199 & 18.1750 & 7.4650 \\
Tension & 200 & 199 & 200 & 199 & 13.4250 & 10.3400 \\
Joy & 200 & 199 & 200 & 199 & 10.9950 & 15.7000 \\
Demands & 200 & 199 & 200 & 199 & 15.6700 & 12.9250 \\
\hline
\end{tabular}




\section{Macrothink}

Table 2. Mean, df, S.D. and t-ratio of total studied sample

\begin{tabular}{lllllll}
\hline Variable & $\mathrm{N}$ & $\mathrm{df}$ & Mean & Std. Deviation & T-value & P-Value \\
\hline Worries & 400 & 398 & 12.8 & 6.12 & 40.2 & $\mathrm{P}<000^{* *}$ \\
Tension & 400 & 398 & 11.8 & 3.10 & 73.3 & $\mathrm{P}<000^{* *}$ \\
Joy & 400 & 398 & 13.3 & 4.42 & 58.0 & $\mathrm{P}<000^{* *}$ \\
Demands & 400 & 398 & 14.2 & 3.68 & 74.9 & $\mathrm{P}<000^{* *}$ \\
\hline
\end{tabular}

$*=.05$ level of significance $\quad * *=.01$ level of significance

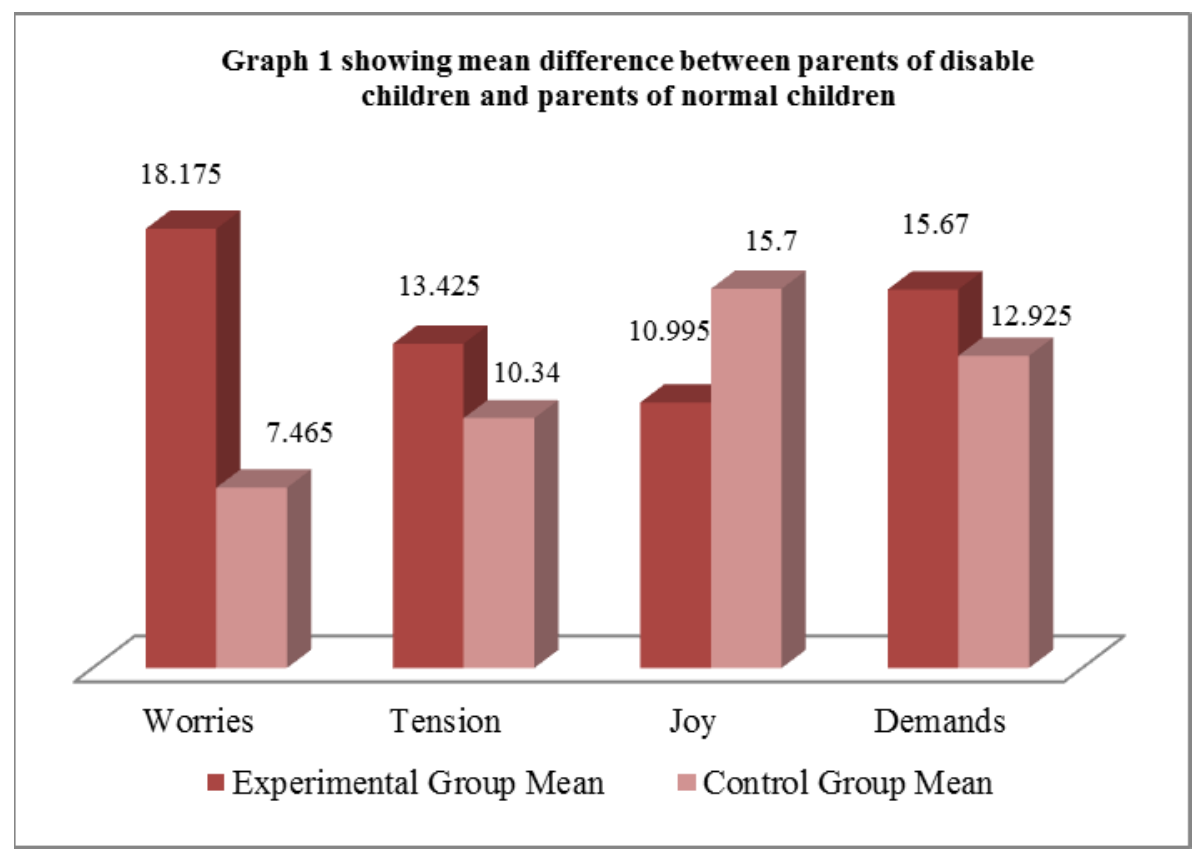

\subsection{Need Assessment of Families}

The purpose of using NASF-PWD tool was to determine the specific requirements of the parents as the same can help in planning better future services.

Area I: Need to Know the Condition of Child: Parents were enquired regarding their interest in knowing about the situation of disabled child. Table 3 shows that in all, $67.5 \%$ of the parents were willing to know about the child disability. Hence, the impact was quite high. $31.5 \%$ of the parents were reluctant in knowing about the disability and its implications. This indicates lesser cognizance among the parents, who instead of recognizing the disability accept it as their destiny.

Table 3 further shows that $74 \%$ of the parents were interested in getting the information 
pertaining to the ability of their child in performing specific task. This indicates higher impact on the part of the parents. 25.5\% of the parents had little impact on this aspect. Hence, the literacy of the parents plays a vital role in determining the attitude of the parents toward their children.

Table 3. Need Assessment of Families of Children with Disability

Area-I (Need to know condition of child)

\begin{tabular}{|c|c|c|c|c|c|c|c|}
\hline \multirow[t]{2}{*}{ Sr. } & \multirow[t]{2}{*}{ Areas } & \multicolumn{2}{|c|}{$\begin{array}{c}2 \\
\text { Impact is } \\
\text { very much }\end{array}$} & \multicolumn{2}{|c|}{$\begin{array}{c}1 \\
\text { Impact is } \\
\text { little }\end{array}$} & \multicolumn{2}{|c|}{$\begin{array}{c}0 \\
\text { No impact }\end{array}$} \\
\hline & & No. & $\%$ & No. & $\%$ & No. & $\%$ \\
\hline 1. & Information on child disability & 135 & 67.5 & 63 & 31.5 & 2 & 1 \\
\hline 2. & $\begin{array}{l}\text { Information on what your child will be } \\
\text { able to do }\end{array}$ & 148 & 74 & 51 & 25.5 & 1 & 0.5 \\
\hline 3. & $\begin{array}{l}\text { Information on special diet of disable } \\
\text { child }\end{array}$ & 120 & 60 & 68 & 34 & 12 & 6 \\
\hline 4. & $\begin{array}{l}\text { Information on Training / medical } \\
\text { facility for disable child }\end{array}$ & 144 & 72 & 51 & 25.5 & 5 & 2.5 \\
\hline 5. & $\begin{array}{l}\text { Information on family / parents having } \\
\text { such disabled child }\end{array}$ & 88 & 44 & 82 & 41 & 30 & 15 \\
\hline
\end{tabular}

Regarding the nutritional and special dietary supplements meant for the disabled child, $60 \%$ of the parents were looking for the information, followed by $34 \%$ parents having casual approach in this regard. Parents were enquired to know their requirement and concern regarding the training / medical facility for their disabled child. In all, $72 \%$ of the parents showed their curiosity in getting information on medical facility. $25.5 \%$ of the parents were disinclined in getting this information. While interviewing the parents it was found that $44 \%$ of the parents want information on families having similar disabled child, whereas $15 \%$ of the parents felt no need of recognizing about the same.

Area II: Child Management: While accessing the needs of the parents, the issues concerning the child management was queried. Table 4 shows that $66.5 \%$ of the parents showed their interest in getting the information on bringing-up of disabled child. Thirty two percent of the parents showed lesser interest in this regard. This showed that the area related to upbringing of the child need to be strengthened. Parents expressed relatively lesser interest in issues related to the care of disabled child. This is indicative of the fact that the educational status of the parents shapes their awareness level. While discussing the issues related to the management of behavioral problems in disabled child, it was found that $66.5 \%$ of the parents were keen in getting this information. Hence, the impact was high as compared to $31.5 \%$ of the parents having lesser interest.

Table 4 reveals that $59.5 \%$ of the parents were interested in knowing about the training of child in activities of daily living, while $36 \%$ of the parents were having lesser interest. While 
getting the opinion from parents regarding the difference between disabled and normal child, it was found that only $46 \%$ of the parents want to get this information, while $21.5 \%$ of the parents had no interest in the same. This is indicative of the fact that because of their own exertions and higher stress level, the parents want to confine themselves up to their own problems.

Table 4. Need Assessment of Families of Children with Disability Area-II (Child Management)

\begin{tabular}{|c|c|c|c|c|c|c|c|}
\hline \multirow[t]{2}{*}{ Sr. } & \multirow[t]{2}{*}{ Areas } & \multicolumn{2}{|c|}{$\begin{array}{c}2 \\
\text { Impact is } \\
\text { very much }\end{array}$} & \multicolumn{2}{|c|}{$\begin{array}{c}1 \\
\text { Impact is } \\
\text { little }\end{array}$} & \multicolumn{2}{|c|}{$\begin{array}{c}0 \\
\text { No impact }\end{array}$} \\
\hline & & No. & $\%$ & No. & $\%$ & No. & $\%$ \\
\hline 1. & Information on bringing-up your child & 133 & 66.5 & 64 & 32 & 3 & 1.5 \\
\hline 2. & $\begin{array}{l}\text { Information on managing behavior } \\
\text { problems in disable child }\end{array}$ & 133 & 66.5 & 63 & 31.5 & 4 & 2 \\
\hline 3. & $\begin{array}{l}\text { Information on training your child in } \\
\text { ADL activity }\end{array}$ & 119 & 59.5 & 72 & 36 & 9 & 4.5 \\
\hline 4. & $\begin{array}{l}\text { Information on how the child is } \\
\text { different from normal child }\end{array}$ & 92 & 46 & 65 & 32.5 & 43 & 21.5 \\
\hline 5. & $\begin{array}{l}\text { Information on planning for another } \\
\text { child }\end{array}$ & 112 & 56 & 40 & 20 & 48 & 24 \\
\hline
\end{tabular}

Table 5. Need Assessment of Families of Children with Disability Area-III (Services)

\begin{tabular}{|c|c|c|c|c|c|c|c|}
\hline \multirow[t]{2}{*}{ Sr. } & \multirow[t]{2}{*}{ Areas } & \multicolumn{2}{|c|}{$\begin{array}{c}2 \\
\text { Impact is } \\
\text { very much }\end{array}$} & \multicolumn{2}{|c|}{$\begin{array}{c}1 \\
\text { Impact is } \\
\text { little }\end{array}$} & \multicolumn{2}{|c|}{$\begin{array}{c}\text { O } \\
\text { No impact }\end{array}$} \\
\hline & & No. & $\%$ & No. & $\%$ & No. & $\%$ \\
\hline 1. & $\begin{array}{l}\text { Information in deciding training center } \\
\text { /school for your disable child }\end{array}$ & 138 & 69 & 49 & 24.5 & 13 & 6.5 \\
\hline 2. & $\begin{array}{l}\text { Information on professional who can } \\
\text { visit home and train your child }\end{array}$ & 117 & 58.5 & 40 & 20 & 43 & 21.5 \\
\hline 3. & $\begin{array}{l}\text { Information on finding services that } \\
\text { trains you and your family members }\end{array}$ & 116 & 58 & 68 & 34 & 16 & 8 \\
\hline 4. & $\begin{array}{l}\text { Information on appropriate vocational } \\
\text { course for your child }\end{array}$ & 100 & 50 & 88 & 44 & 12 & 6 \\
\hline 5. & $\begin{array}{l}\text { Information on effect of admitting } \\
\text { your child to special school/ normal } \\
\text { school }\end{array}$ & 103 & 51.5 & 70 & 35 & 37 & 18.5 \\
\hline
\end{tabular}


Table 6. Need Assessment of Families of Children with Disability

Area - IV (Personal - Social)

\begin{tabular}{|c|c|c|c|c|c|c|c|}
\hline \multirow[t]{2}{*}{ Sr. } & \multirow[t]{2}{*}{ Areas } & \multicolumn{2}{|c|}{$\begin{array}{c}2 \\
\text { Impact is } \\
\text { very much }\end{array}$} & \multicolumn{2}{|c|}{$\begin{array}{c}1 \\
\text { Impact is } \\
\text { little }\end{array}$} & \multicolumn{2}{|c|}{$\begin{array}{c}0 \\
\text { No impact }\end{array}$} \\
\hline & & No. & $\%$ & No. & $\%$ & No. & $\%$ \\
\hline 1. & Need more time for self & 153 & 76.5 & 45 & 22.5 & 2 & 1 \\
\hline 2. & $\begin{array}{l}\text { Need to talk to someone about your } \\
\text { problem }\end{array}$ & 115 & 57.5 & 78 & 39 & 7 & 3.5 \\
\hline 3. & $\begin{array}{l}\text { Information on marriage issues related } \\
\text { to your disable child }\end{array}$ & 124 & 62 & 31 & 15.5 & 45 & 22.5 \\
\hline 4. & $\begin{array}{l}\text { Help to manage your physical health } \\
\text { problems }\end{array}$ & 147 & 73.5 & 29 & 14.5 & 23 & 11.5 \\
\hline 5. & $\begin{array}{l}\text { Information on sexuality issues related } \\
\text { to your disable child }\end{array}$ & 146 & 73 & 18 & 9 & 36 & 18 \\
\hline
\end{tabular}

Table 7. Need Assessment of Families of Children with Disability Area - V (Unspecified Needs)

\begin{tabular}{|c|c|c|c|c|c|c|c|}
\hline \multirow[t]{2}{*}{ Sr. } & \multirow[t]{2}{*}{ Areas } & \multicolumn{2}{|c|}{$\begin{array}{c}2 \\
\text { Impact is } \\
\text { very much }\end{array}$} & \multicolumn{2}{|c|}{$\begin{array}{c}1 \\
\text { Impact is } \\
\text { little }\end{array}$} & \multicolumn{2}{|c|}{$\begin{array}{c}0 \\
\text { No impact }\end{array}$} \\
\hline & & No. & $\%$ & No. & $\%$ & No. & $\%$ \\
\hline 1. & $\begin{array}{l}\text { Information legislation for the } \\
\text { disabled }\end{array}$ & 164 & 82 & 32 & 16 & 4 & 2 \\
\hline 2. & $\begin{array}{l}\text { Information on Govt. schemes and } \\
\text { benefits for disables }\end{array}$ & 164 & 82 & 35 & 17.5 & 1 & 0.5 \\
\hline 3. & $\begin{array}{l}\text { Financial help to take care special } \\
\text { needs of disable child }\end{array}$ & 156 & 78 & 26 & 13 & 18 & 9 \\
\hline 4. & $\begin{array}{l}\text { Information whether your disable } \\
\text { child could affect normal child }\end{array}$ & 129 & 64.5 & 42 & 21 & 29 & 14.5 \\
\hline 5. & $\begin{array}{l}\text { Information about hostel facility for } \\
\text { your disable child }\end{array}$ & 135 & 67.5 & 39 & 19.5 & 26 & 13 \\
\hline
\end{tabular}

The apprehension in planning for another child was discussed with the parents and it was found that only $56 \%$ of the parents want information on incidence of disability in their next child. Remaining $44 \%$ of the parents showed averseness in this matter. This again point out toward their educational status and awareness level. Most of the parents were unaware about the tests confirming the disability during the pregnancy.

Area III: Services: While administering the Need Assessment Scale for families of persons 
with disability, the parents were interviewed to know their opinion about the training centers / schools for their disabled child. Table 5 shows that $69 \%$ of the parents were eager to know about training centers/schools and admission process. $24.5 \%$ of the parents had lesser interest in getting this information. $6.5 \%$ of the parents had no interest in admitting the disabled child to such institutions. The reason behind the lack of awareness was the nature of disability.

Parents were enquired about the requirement of professional who can visit their home and train their child. $58.5 \%$ of the parents were in favor of this service while $20 \%$ of the parents were not very keen of getting this type of service. $21.5 \%$ of the parents were not at all interested in the services offered by the professional. Table 5 shows that $58 \%$ of the parents were interested in getting themselves trained in taking care of their disabled child. $34 \%$ of the parents had a cold response in this matter.

While assessing the needs of the parents regarding the appropriate vocational training for the disabled child, $50 \%$ of the parents were enthusiastic in getting this information, while $44 \%$ of the parents were not very keen to have this information. This shows that the literacy of parents plays a vital role in determining their attitudes and child rearing practices.

While interviewing the parents, it was found that $51.5 \%$ of the parents want admit their child to special school meant for disabled children, while 35\% of the parents were little reluctant in this regard. $18.5 \%$ of the parents were not interested in educating their disabled child in special school. The reason here is lack of awareness on the part of the parents and the critical condition of some children having severe mental disability, which stops them from opting for special schools.

Area IV: Personal-Social: Table 6 highlights the personal/social needs of the parents having disabled child. $76.5 \%$ of the parents felt that they have no time for themselves; their most of the time is consumed in taking care of disabled child. Table 6 shows that $57.5 \%$ of the parents were so frustrated that they want to share their problem and felt the need of discussing and talking to someone who can understand them and their problems. While 39\% of the parents had casual approach in this regard, i.e. they partially want to share their problem but at the same time they want to confine themselves to their own problem. 3.5\% of the parents don't want to discuss anything.

Since the parents are the main care-providers for their disabled children, they are apprehensive of knowing certain critical issues, for instance, issues related to marriage, sexuality etc. $62 \%$ of the parents were keen in knowing the issues related to the marriage of their disabled child. $15.5 \%$ of the parents showed lesser interest while, $22.5 \%$ of the parents were not interested in knowing anything pertaining to marriage. The reason behind this was the critical condition of the child, which hampers them from this.

The parents of disabled children remain busy throughout the day. This affects their physical and mental health. They want help to manage their problems related to their physical health. $73.5 \%$ of the parents want help in keeping their physical health in proper condition. $11.5 \%$ of the parents don't want anyone's to interference in their personal life.

The issue of sexuality of disabled child is a matter of great concern for the parents. Because 
of underdevelopment or delayed development, the disabled children are sexually immature. While interviewing the parents, it was found that $73 \%$ of the parents were eager to get detailed information on this matter, while $9 \%$ had a mixed response. Thus, it was found that though few parents were reluctant, most other were keen to know about the sensitive issues linked with their children. They are so deeply impacted by the child disability that they find no time for themselves. Being fatigued they want outside help and proper guidance to keep themselves motivated. The present situation needs an intervention, which can enhance the motivation level of parents and reduce their stress so that they can effectively render their duties.

Area V: Unspecified Needs: There are numerous schemes and programs, meant for disabled children, which are initiated by the Center and State Government. In addition to this, there are certain legislative provisions and reforms whose information must be provided to the parents. Table 7 shows that in all $82 \%$ of the parents want to get information on legislative provisions.

$82 \%$ of the parents were interested in getting the information regarding the various schemes and benefits meant especially for the disabled children, while $17.5 \%$ of the parents were comparatively less aware of the schemes and programs. Disability not only disturbs the social and personal life of family, but also affects the financial condition of the parents. The condition gets deteriorated if the family is poor or below poverty line. A huge amount of money is required for providing proper medical care and fulfilling special needs of disabled children. $78 \%$ of the parents responded that they need financial help to take care of their disabled child while $13 \%$ of the parents had a cold response. $9 \%$ of the parents don't require any financial help.

$64.5 \%$ of the parents were interested in getting information on the issue where the disabled child can affect their normal child, while $14.5 \%$ of the parents don't want any sort of information in this regard. There are special hostels / institutions, which are meant for disabled children, which provide special care and train the children accordingly. $67.5 \%$ of the parents were interested to get information about the special hostel facility meant for their child. No parent in the world would like to have a disabled child; however, once they have a disabled child, they have no choice left but to nurture the child. Birth of a child with different abilities is a shock for them. Hence, they have special needs for the child. These needs are quite complex and necessitate development of support programs for parents and families.

\section{Discussion}

In the recent years, there has been a transition in the provision of health care services from child-centered paradigm to a family-centered paradigm (Friesen \& Koroloff, 1990; Bamm \& Rosenbaum, 2008). According to Siebes et al. (2007), parents are usually the main members of a family and the role of parents in the psychotherapy of disabled children is gradually being acknowledged. Active involvement of parents at all stages of medication and handling of disabled children is an essential component of overall management. It was found during the study, that rendering a high level of care required by children with disabilities disturbs the psychosomatic wellbeing of parents. Present study is in accordance with the study conducted by Wallander et al. (1990) and Dyson (1993). Parents suffer from emotional problems, for 
instance, depression, anxiety, fear and worries, which restrain their role in the management of child's disability. Similar results were reported by Bartlett (2004) in his study on maternal depressive symptoms in children with asthmatic problems. Studies carried out in the past shows that the parents of children with disabilities are subjected to more stress because of fears, concerns and burdens related to their child (Floyd \& Gallagher, 1997; Minnes, 1998). The results of the present study confirmed the earlier result outcomes showing that parents of disabled children experience significantly more stress than parents of normal children. Furthermore, Baker et al. (2003) also established that parenting stress was higher for parents of preschoolers with delays than for parents of normal preschoolers. Based on the results of this study, it seems that the conventional thinking molds insights, practices and outlooks of caregivers and community. These dogmas are consecutively linked with the religious, socio-economic status and educational qualifications of the families of children with special needs.

It was found that emotive suffering in parents is adding to the psychiatric problem of disabled child and upsetting family's capability in handling the situation, thereby affecting the family. Findings of study are in harmony with the study conducted by Canning et al. (1993), who studied the incidence of distress among the mothers of chronically ill children.

The present study examined the reasons that impact upon the level of parental stress linked with caring of children having developmental disabilities. The results indicate significant and positive relationship between the occurrence of disability and parental stress. The mean difference is highly significant for the present study and the results of present study are in accordance with the earlier evidences. The findings are consistent with studies conducted by McDonald, 1996 which indicate that trouble of care-giving tasks; problematic child behavior during care-giving chores (Hastings, 2002) and child disability (Haveman et al., 1997) are associated with parental stress. Shultz and Quittner (1998) showed that the stress level of parents having disable children is high and it leads to disruption to family routines and activities. The findings of the study established that tougher care-giving duties lead to higher level of parental stress.

Level of stress was found higher in parents of children having more severe disabilities. However, while it is often reported that child's behavior is the main blamable factor for parental stress, the study advocates that trouble of care-giving job is the best interpreter of stress level. The results propose the need for more research to explore which precise aspects of care-giving tasks are problematic for parents. Circumstantial causes such as lack of knowledge and complication of tasks are probably the areas, which require exploration. Parents explained that they require a helping hand for managing their disabled child during feeding, cleaning up, relaxing the child at bed and toileting. The present study has added to the prevailing research in that it analytically addressed a number of key variables related to parental stress. While interviewing the parents of the children, it was found that caring for a disable child involves accomplishment of tasks with prolonged hours periods and energy, which causes repeated disturbance in family schedules and activities. In addition to the assessment of perceived stress among parents having disabled children, the study also examined the special needs of parents under five domains such as need to know condition of 
child, child management, exceptional facilities, personal-social backing and unspecified necessities.

The results of the study revealed that most of the parents need proper information and guidance about the child's condition or disability and financial support, besides special requirements of child, community services and skilled support.

Parents preferred a resilient necessity of information relating to future and current services available for relieving their burden. A large number of parents expressed that they need information on special educational institutions meant for disabled children. Regarding the nature of requirements expressed by parents, the pattern described by parents in the present study is in accordance with those reported in previous researches (Baily et al., 1992; Cooper and Allred, 1992; Sexton et al., 1992; Garshelis and Mc Connell, 1993; Barnhart et al., 1994; Bailey and Simeonssion, 1988). Many parents expressed the desire to know the child's disability and technique of handling them. Walker et al. (1989) also reported that the parents of children with chronic health disorders conveyed needs for information about child's condition, treatment and long-term implications of disability. Parents also expressed their needs for information regarding the government schemes and programs and the findings of present study are consistent with previous findings for families having disabled children (Sloper \& Turner 1992; Ellis et al., 2002).

It was also seen that parents and society should both be made aware of children with disability and their specific needs. It would diminish the emotions associated with of self-blame, dependence and isolation among the parents, and provide a hope for the future. Moreover, cognizance regarding the management of disable child decreases the additional workload and lessens the emotional instabilities among parents (Thorburn, 2006).

The findings of the study imply that the prevalence of child disability can be abridged by improving educational levels of mothers, by raising household living standards, by improving environmental conditions and by linking education and health. Such efforts should be combined with programmes that raise parent's awareness of disability and special requirements of children with disability. To achieve this, a thoughtful consideration is required. It is not that the knowledge possessed by parents is altogether outdated but it has to be handled in such a way that all that is good may be retained or further improved by synthesizing it with modern science and all that is not required and can have negative impacts may be turned down. This requires the support of governmental and non-governmental organizations concerned with the matter and who really want to improve the situation. The present study did not look into the biasness in handling of male and female children with disabilities; future investigations could look at the gender issues linked with disabilities.

The findings of the study can be used in improving models of services and execution of Government policies for disabled children and their families, confirming that parent's viewpoints are taken into consideration. Realizing what, when, and how awareness programs can be initiated and implemented becomes important to ensure the provision of proper care. This in turn can help modify programs and services to achieve effective results for children with disabilities. 


\section{Conclusion}

The study concludes that parents of children with developmental disability are at increased risk of stress. Disabled children rely on parents to meet their needs, who at times find burdensome situation, and as a result feel more stressed. Child disability is a strong predictor of child related parenting stress. The study supports the need of counseling of parents with developmental disabilities. There is need of educating parents, running programs involving management \& planned activities, trainings or combination of these. The results act as a benchmark for the intervention programs destined for families of children with developmental infirmities. It is further proposed that parents must be involved in planning process. It was conclusively found that there is need of intervention for early detection of parents who are at risk of depression and similar state of mind because such concerns will be more fruitful if they focus at amendable determinants of parenting and concentrate on parental requirements. The study supported the necessity of evolving medical pathways having bio-psychosocial frameworks that are focused on family, not merely the practical or temporary restoration interventions that are largely child specific. Since most of the parents need information about services and financial support provided by the government, this calls for intervention of policy makers and dedicated non-governmental organizations, which can facilitate and bridge the gap. The results of the study must help in evolving intervention programs and strengthening of counselling of parents having children with disabilities.

\section{Acknowledgement}

The authors gratefully acknowledge the support and help provided by Department of Social Justice and Empowerment, Government of Himachal Pradesh to conduct the study. They thank all the staff for their support and advice during the study.

\section{References}

Abidin, R. R. (1995). Parenting Stress Index. Charlottesville, VA: Pediatric Psychology Press.

Agrawal, U. N., Malhan, N. K., \& Singh, B. (1979). Some classifications of stress and its applications at work. Ind. J. Indus. Rel., 15(1), 41-50.

Bailey, D. B., \& Simeonsson, R. J. (1988). Assessing needs of families with handicapped $\begin{array}{lllll}\text { infants. Journal of Special Education, } & 22,\end{array}$ http://dx.doi.org/10.1177/002246698802200113

Bailey, D. B., Blasco, P. M., \& Simeonsson, R. J. (1992). Needs expressed by mothers and fathers of young children with disabilities. American journal on Mental Retardation, 97, 1-10.

Baker, B. L., McIntyre, L. L., Blacher, J., Crnic, K., Edelbrock, C., \& Low, C. (2003). Pre-school children with and without developmental delay: Behaviour problems and parenting stress over time. Journal of Intellectual Disability Research, 47, 217-230. http://dx.doi.org/10.1046/j.1365-2788.2003.00484.x 
Bamm, E. L., \& Rosenbaum, P. (2008). Family-centered theory: origins, development, barriers, and supports to implementation in rehabilitation medicine. Arch. Phys. Med. Rehabil., 89, 1618-24. http://dx.doi.org/10.1016/j.apmr.2007.12.034

Barnhart, L. L., Fitzpartrick, V. D., Sidell, N. L., Adams, M. J., Shields, G. S., \& Gomez, S. J. (1994). Perception of family need in pediatric oncology. Child and Adolescent Social work Journal, 11,137-148. http://dx.doi.org/10.1007/BF01875772

Bartlett, S. J., Krishnan, J. A., Riekert, K. A., Butz, A. M., Malveaux, F. J., \& Rand, C. S. (2004). Maternal depressive symptoms and adherence to therapy in inner-city children with asthma. Pediatrics, 113, 229-37. http://dx.doi.org/10.1542/peds.113.2.229

Canning, E. H., Hanser, S. B., Shade, K. A., \& Boyce, W. T. (1993). Maternal distress and discrepancy in reports of psychopathology in chronically ill children. Psychosomatics, 34, 506-11. http://dx.doi.org/10.1016/S0033-3182(93)71825-3

Cooper, C. S., \& Allred, K. W. (1992). A comparison of mother's versus father's needs for support in caring for a young child with special needs. Infant-Toddler Intervention, 2, 205-221

Dyson, L. L. (1993). Response to the presence of a child with disabilities: parental stress and family functioning over time. Am. J. Ment. Retard., 98, 207-18.

Ellis, J. T., Luiselli, J. K., Amirault, D., Byrne, S., O‘Malley Cannon, B., Taras, M., Wolongevicz, J., \& Sisson, R. W. (2002). Families of children with developmental disabilities: assessment and comparison of self-reported needs in relation to situational variables. Journal of Developmental and Physical Disabilities, 14, 191-202. http://dx.doi.org/10.1023/A:1015223615529

Fliege, H. et al. (2004). The Perceived Stress Questionnaire (PSQ) Reconsidered: Validation and Reference Values from Different Clinical and Healthy Adult Samples. Psychosomatic Medicine, 67, 78-88. http://dx.doi.org/10.1097/01.psy.0000151491.80178.78

Floyd, F. J., \& Gallagher, E. M. (1997). Parental stress, care demands, and use of support services for school-age children with disabilities and behavior problems. Family Relations, 46, 359-371. http://dx.doi.org/10.2307/585096

Friesen, B. J. \& Koroloff, N. M. (1990). Family-centered services: implications for mental health administration and research. J. Ment. Health Adm., 17, 13-25. http://dx.doi.org/10.1007/bf02518576

Garshelis, J. A., \& McConnell, S. R. (1993). Comparison of family needs assessed by mothers, individual professionals and interdisciplinary teams. Journal of Early Intervention, 16, 36-49. http://dx.doi.org/10.1177/105381519301700105

Hassall, R., Rose, J., \& McDonald, J. (2005). Parenting stress in mothers of children with an intellectual disability: The effects of parental cognitions in relation to child characteristics and family support. Journal of Intellectual Disability Research, 49, 405-418. http://dx.doi.org/10.1111/j.1365-2788.2005.00673.x 
Hastings, R. P. (2002). Parental stress and behavior problems of children with developmental disability. Journal of Intellectual and Developmental Disability, 27(3), 149-160. http://dx.doi.org/10.1080/1366825021000008657

Haveman, M., Berkum, G. V., Reijnders, R., \& Heller, T. H. (1997). Differences in service needs, time demands, and care-giving burden among parents of persons with mental retardation across the life cycle. Family Relations, 46(4), 417-425. http://dx.doi.org/10.2307/585101

Lavee, Y., Sharlin, S., \& Katz, R. (1996). The effect of parenting stress on marital quality. Journal of Family Issues, 17, 114-135. http://dx.doi.org/10.1177/019251396017001007

Lazarus, R. S., \& Folkman, S. (1984). Stress appraisal and coping. New York: Springer

McDonald, T. P., Couchonnal, G., \& Early, T. (1996). The impact of major events on the lives of family caregivers of children with disabilities. Families in Society: The Journal of Contemporary Human Services, 10, 502-514. http://dx.doi.org/10.1606/1044-3894.960

Miller, A.C., Gordon, R. M., Daniele, R. J., \& Diller, L. (1992). Stress, appraisal and coping in mothers of disabled and nondisabled children. Journal of Pediatric Psychology, 17, 587-605. http://dx.doi.org/10.1093/jpepsy/17.5.587

Minnes, P. M. (1998). Mental Retardation: The impact upon the family. In J. A. Burack, R. M. Hodapp, \& E. Zigler (Eds.), Handbook of mental retardation and development. New York: Cambridge University Press.

Nachshen, J. S., Garcin, N., \& Minnes, P. (2005). Problem behaviour in children with intellectual disabilities: Parenting stress, empowerment and school services. Mental Health Aspects of Developmental Disabilities, 8,105-114.

Pal, D. K., \& Choudhury, G. (1998). Preliminary validation of a parental adjustment measure for use with families of disabled children in rural India. Child Care, Health and Development, 24, 315-324. http://dx.doi.org/10.1111/j.1365-2214.1998.tb00950.x

Ranta, R. S., Sharma, V. K., Negi, B. S., \& Gupta, P. (2014). Child Disability: Impact on Child, Family \& Social Environment. A Report submitted to Department of Social Justice and Empowerment, Govt. of Himachal Pradesh (Unpublished)

Rao, S. K. R (1983). The conception of stress in Indian thought: The theoretical aspects of stress in Samkhya and Yoga system. Nimhans Journal, 2, 115-21.

Selye, H. (1978). The Stress of Police Work. Police Stress, 1, 7-8.

Sexton, K., Burrell, B., \& Thompson, B. (1992). Measurement integrity of the Family Needs Survey. Journal of Early Intervention, 16, 343-352. http://dx.doi.org/10.1177/105381519201600405

Shultz, R., \& Quittner, A. L. (1998). Caregiving for children and adults with chronic conditions: introduction to the special issue. Health Psychology, 17, 107-11. http://dx.doi.org/10.1037/h0092707 


\section{Ml Macrothink}

International Journal of Social Science Research

ISSN 2327-5510

2015, Vol. 3, No. 2

Siebes, R. C., Wijnroks, L., Ketelaar, M., Van Schie, P. E., Gorter, J. W., \& Vermeer, A. (2007). Parent participation in pediatric rehabilitation treatment centers in the Netherlands: a parents' viewpoint. Child Care Health Dev., 33, 196-205. http://dx.doi.org/10.1111/j.1365-2214.2006.00636.x

Singh, T. K., India, V., \& India, R. R. (2008). Impact of disability of mentally retarded persons on their parents. Indian Journal of Psychological Medicine, 30(2), 98-104. http://dx.doi.org/10.4103/0253-7176.48482

Sloper, P., \& Turner, S. (1992). Service needs of families of children with severe physical disability. Childcare, health and development, 18, 259-282. http://dx.doi.org/10.1111/j.1365-2214.1992.tb00359.x

Stein, R. E. K. (1988). Caring for Children with Chronic Illness: Issues and Strategies. New York: Springer Publishing Company.

Tew, B., \& Laurence, K. (1975). Some sources of stress found in mothers of children with spina bifida. British Journal of Preventive and Social Medicine, 29, 27-30. http://dx.doi.org/10.1136/jech.29.1.27

Thorburn, M. J. (1993). Attitudes towards childhood disability in three areas in Jamaica. West Indian Med Journal, 42(1), 10-12.

Verma, R. K., \& Kishore, M. T. (2009). Needs of Indian parents having children with intellectual disability. International Journal of Rehabilitation Research, 32(1), 71-76. http://dx.doi.org/10.1097/MRR.0b013e32830d36b6

Walker, D. K., Epstein, S. G., Taylor, A. B., Crocker, A. C., \& Tuttle, G. A. (1989). Perceived needs of families with children who have chronic health conditions. Children's Health Care, 18, 196-201. http://dx.doi.org/10.1207/s15326888chc1804_1

Wallander, J. L., Pitt, L. C., \& Mellins, C. A. (1990). Child functional independence and maternal psychosocial stress as risk factors threatening adaptation in mothers of physically or sensorially handicapped children. J. Consult. Clin. Psychol., 58, 818-24. http://dx.doi.org/10.1037/0022-006x.58.6.818

\section{Copyright Disclaimer}

Copyright for this article is retained by the author(s), with first publication rights granted to the journal.

This is an open-access article distributed under the terms and conditions of the Creative Commons Attribution license (http://creativecommons.org/licenses/by/3.0/). 